\title{
On the Measures to Solve Environmental Problems of the Territory with Intensive Open Pit Coal Mining
}

\author{
Tatiana Gvozdkova ${ }^{1}$, Pawel Stefanek ${ }^{2}$ and Michaela Koščová3, \\ ${ }^{1}$ Kuzbass State Technical University, Mezhdurechensk branch, 652881, Stroitelei Avenue, 36, \\ Mezhdurechensk, Russia \\ ${ }^{2}$ KGHM Polska Miedź SA, Hydrotechnical Division, 59-305 Rudna, Polkowicka 52, Poland \\ ${ }^{3}$ Comenius University, Department of Applied Mathematics and Statistics, 84248 Mlynska dolina \\ Bratislava, Slovakia
}

\begin{abstract}
Ecological problems in the open pit mining of coal deposits are extremely hard, since mining operations are accompanied by disturbed land to a large depth with significant changes in the landscape, hydrometeorological conditions, mixing of rocks and removal of infertile or even harmful rocks with radioactive isotopes to the surface. Disturbed lands are unusable if they are not repaired. All man-made disturbances of the environment caused by open pit mining are divided into landscape (changes in terrain, vegetation and soil cover) and environmental (violation of living conditions within the allotment and adjacent lands: changes in water regime, pollution of the soil, air and water basins) onesOne of the most important areas in the field of environmental protection is the reclamation (restoration) of the earth's surface. In accordance with the requirements of the protection of the subsoil, enterprises engaged in the development of mineral deposits are obliged at their own expense to bring disturbed lands into a state suitable form for their further use. Reclamation of ought to be carried out during open pit mining operations and must be completed after mining of mineral resources in the terms established by the authorities that provide land for use.
\end{abstract}

\section{Introduction}

The upper part of the lithosphere, which directly acts as the mineral basis of the biosphere, is currently undergoing an ever-increasing anthropogenic impact. In the era of rapid economic development, when practically the entire biosphere of the planet was involved in the production process, the human became "the largest geological force" under whose influence the face of the Earth changes [1]. The scientific-and- technical progress leads to qualitatively and quantitatively increasing consumption of lithospheric resources.

Already today, human impact on the lithosphere is approaching the limits, the overcoming of which cause irreversible processes over almost entire surface (the part of the Earth core). In the process of converting the lithosphere, humanity extracted 150 billion tons of coal, more

\footnotetext{
*Corresponding author: michaela.koscova@fmph.unibqa.sk
} 
than 120 billion tons of other minerals [2]. Over the past hundred years, erosion has destroyed 2 million hectares, the area of ravines exceeded 25 million hectares [3]. The heaps exceeded the height of $300 \mathrm{~m}$, the dumps - $250 \mathrm{~m}$ [4]. However, the ecological function of the lithosphere is expressed in that it is the basic subsystem of the biosphere: the entire continental and almost all marine biota rests on the Earth core. For example, technogenic destruction of a minimum layer of rocks on land or on the marine shelf automatically destroys the biocenosis.

Almost all chemical elements are used in practice. However, only about one-seventh of the extracted minerals are used in the production of finished products. Waste disposal and storage is expensive. Their costs can be up to $30 \%$ of the cost of annual production [5]. Nevertheless, valuable and scarce minerals fall into the waste: refractory clay, phosphate rock, dolomite, limestone, quartzite, etc. Only one fifth of the slags of non-ferrous metallurgy is involved in the turnover.

Open pit mining (quarrying) is the way to decrease losses of minerals during extraction process. Quarries are artificial geological and geographical objects, created as sites for the extraction of certain minerals by the open pit method. The quarry is also a set of excavations in the earth's core, formed during the mining of minerals from the surface. In Russia, the term "open cut" is also used with reference to open pit mines [6].

Being created artificially, quarries exist only as long as the people supports them. As a rule, environmentalists consider a pit only as a negative phenomenon, since when it is created, the soil cover is broken, trees are cut down, and the balance regime of groundwater is disturbed [7]. Explosions and noise produced my open pit mining technology scare animals and birds. Therefore, the quarries can have many different negative influences on the environment.

Coal mining is accompanied by the destruction of soil cover and natural landscapes during mining operations. First, due to mining, the geological environment is destroyed. As a result of the development of mineral deposits, there is a complete change in topography, a violation of the water, air and food regime of the soil, which leads to a violation of the biogeocenosis as a whole.

\section{Materials and Methods}

In the depths of the Kuzbass (the largest coal basin in Russia) a huge number of diverse raw materials is concentrated, which comprises $36.4 \%$ of the volume of mineral resources available in Russia [8].

In the Kemerovo region coal, iron, gold, silver, zinc, lead, manganese are mined. There are rich deposits of phosphate rock and other high-value raw materials. A large concentration of industrial production has a strong negative effect on the environment and humans.

In connection with exploration and active development of mineral deposits, the level of ecologically permissible impact on the biosphere is exceeded and there is a real threat of irreversible man-made pollution of the biogeocenosis.

The carrying out to the surface of the enormous mass of deep rocks (in Kuzbass it is about 15 billion $\mathrm{m}^{3}$ ) led to surface precipitation processes, changes in the terrain relief, the formation of depression craters, and the destruction of the existing natural biocenoses. Carboniferous rocks brought to the surface often contain easily oxidized pyrite and heavy metals. Their concentration can be dangerous to humans and animals [9].

In the Kuznetsk coal basin, the area of deposits suitable for open pit mining is 360 thousand hectares (20\% of all the sown areas of the Kemerovo Region). Most of them are located between the Tom' and Inya rivers with the coverage of puffy black soil [10]. At present, it is difficult to predict the timing of the development of all coal deposits. The areas of disturbed land will constantly increase. Already, with the open pit mining of coal, about 
25 thousand hectares of land are disturbed annually. The total area of land disturbed by coal industry (along with various communications) is about 2 million hectares [11].

Because of mining operations in Kuzbass, more than 60 thousand hectares of fertile land were disturbed and taken out of circulation and about 300 small rivers were destroyed. In the region, there are more than 500 enterprises that violate the soil cover. Among the largest soil breakers are open pit coal mining enterprises, which are responsible for more than $60 \%$ of the total land area damage [12].

Of the total area of the land disturbed by open pits, quarry excavations make up 33.9\%, external dumps $-42.5 \%$, internal dumps $-13.0 \%$, and other violations $-10.6 \%$ [13]. At the same time, a whole complex of negative environmental consequences arises, the main of which is the reduction of the area of natural landscapes, the emergence of lifeless wastelands in their place, pollution of the surrounding territories with water and wind erosion products.

Erosion is the destruction and demolition of the upper most fertile layers and underlying rocks by wind (wind erosion) or water flows (water erosion). Earth, destroyed in the process of erosion, is called eroded. One of the main causes of erosion is the development of quarries. Erosion has a significant negative impact on the state of the soil cover, and in many cases destroys it completely. The biological productivity of plants decreases, therefore the harvests also decrease.

Wind erosion (deflation) means the blowing, transfer and deposition of the smallest soil particles by the wind. The intensity of wind erosion depends on wind speed, soil stability, vegetation cover, topography, and other factors. Anthropogenic factors have a huge impact on its development. For example, the destruction of vegetation, during the clearing of sites for the extraction of minerals.

Not only the quarries themselves have a negative impact on the environment, but also many other factors associated with them. For example, heavy mining equipment and rock dumps resulting from mining. Heavy machinery disrupts the structure of the soil layer, which leads to a decrease in the stability of water erosion. Since the equipment goes to a quarry along the same route, and it forms deep traces of caterpillars, which subsequently may become full-fledged ravines and entail subsequent erosion. In addition, as a rule, when mining by the open method, a huge amount of dust rises into the air, including coal dust, which, carried by the wind, can also have a negative impact, for example, on plants.

Dumps can be sources of emissions of various substances. The main component of emissions is water vapor. Together with vapor-gas emissions into the atmosphere from the side of the dumps, volatile compounds of toxic elements - mercury, arsenic, cadmium, etc. can get out. Emissions from the dumps can spread hundreds of meters, capturing large zones, including residential areas. Emission components, settling on the earth's surface, pollute the ground forming the halos dispersion. The most polluted are the marshy areas of river valleys and the bottoms of hollows.

The dumps and halos of dispersion of pollutants in soils themselves are sources of pollution of the aquatic environment by sulphates and toxic components. At the same time, surface runoff that leaches soluble sulphates from the surface of waste heaps and dumps, and groundwater in the process of infiltration of toxic premixes, are polluted too.

Negative geological processes associated with dumps, are manifesting in various aspects. Water erosion of dump slopes leads to the expansion of their area. The rock mass exerts additional pressure on the base soils, which can affect the change in their filtration properties and have a local effect on the level regime of the first aquifer. However, dumps have the most significant negative effect due to the formation of replacement zones in the soils of the aeration zone and in water-bearing rocks. They are manifested by the development of secondary mineralization.

Under natural conditions, this mineralization is represented in the form of an abundance of vein-disseminated carbonates, developing in the aeration zone and in water-bearing rocks. 
Within the fault zones, not only the amount of gypsum increases, but also the size of the discharge, reaching $15-20 \mathrm{~cm}$ in diameter. Vertical zonality manifests itself when nodules and streaks of earthy aggregates of soda minerals are released in the upper part of the aeration zone, plaster appears down the section, which then becomes the main technogenic mineral. This zonality is due to the different solubility of soda minerals and gypsum in water. The replacement zones are accompanied by the redistribution of the major part of macro- and microcomponents both in the soils of the aeration zone and in water-bearing rocks and in groundwater. The conductors of these processes are faults or geodynamic active zones.

\section{Results and Discussion}

The main method of restoration of natural systems is reclamation of disturbed lands. The main requirement of biological reclamation should be its high ecological efficiency.

The best option is the complex reclamation in various areas, with the goal of creating a new landscape unit.

Reclamation works are divided into mining and biological ones. The tasks of the mining technical reclamation is the formation of dumps of such a configuration, in which subsequent use of land for plantations, cultivation of crops and the creation of pastures is possible; removal, storage and deposition on the surface of the dumps of the fertile layer; carrying out melioration and other events.

The removal of the soil layer and its laying in piles up to $10 \mathrm{~m}$ high are done by bulldozers, scrapers, loaders, and sometimes construction excavators in conjunction with road transport. Temporary warehouses of fertile and potentially fertile soils must be located, as far as possible, near objects or territories that are subject to further reclamation. To prevent wind and water erosion, grass should be sown on their surface. Soil storage time in temporary stocks is not more than 10 years. The excavation of these rocks from the piles is carried out by excavators or single-bucket loaders with shipment to the dump trucks. Wheel scrapers and hydraulic delivery are also effective. Hydraulic laying of soils contributes to the creation of a favorable relief, preservation of the structure and basic agrotechnical properties of soils.

The technical reclamation takes up to $80 \%$ of the total costs intended for reclamation. When combining reclamation with the main technological processes, costs can be reduced by more than two times.

Biological reclamation on the land intended for use in agriculture and forestry is carried out by land users at the expense of the mining companies that have been developing mineral deposits. It accounts for $20-25 \%$ of the total cost of restoring disturbed areas. It includes a set of works for land improvement and fertilization with microorganisms, special crop rotations, planting trees and shrubs (the cheapest and easiest way of biological development of disturbed lands) and other measures aimed at restoring fertility and economic value of land.

When pilling dumps, a significant amount of dust is also emitted, for the deposition of which stationary or mobile irrigation installations must be used. External temporary dumps and coal warehouses enclose anti-dust reinforced concrete fences or forest stands. Forest plantations on dumps give a good effect.

To protect the population from dust carried away by the wind from the dumps, it is necessary to locate residential areas on the windward side, surrounding them with a green belt from plants that are resistant to pollution. One hectare of greenery humidifies and refreshes the air 10 times more than a water basin of the same area. Vegetation is mechanically delayed by foliage of some of the pollution; it binds and neutralizes some compounds. To reduce air pollution in the vicinity of existing facilities of a mining enterprise is possible by reducing the time gap between mining and reclamation by intensive build-up of dumps to the design height. 
Block mining of vast deposits allows us to adopt a mining procedure in which the overburden movement from a lagging block to a leading block occurs on the short transport radius $(2.0-2.5 \mathrm{~km})$ without changing the direction of cargo flow (the overburden is in the same area as the dump), without going to the surface. At the same time, not only the costs for field development are reduced, but also favorable conditions are created for the formation of technogenic landscapes on dumps in the advanced block. It is necessary for the earliest possible technical and biological reclamation start in order to reduce the time needed for the reclaimed lands to be returned.

In practical reclamation, the main goal is to compensate for the economic and environmental damage caused to the soil cover. The modern soil science has a set of technological methods, which allows forming a soil-like body (technosoil) with a high level of stable dynamic functions.

The first stage in the development of the surface of the dumps is the creation of a grassy cover that can influence the soil-forming process, prevent dusting and leaching of small particles. Sowing rhizomatous and turfy perennial grasses (wheatgrass grass, livegrass bluegrass, feather grass, steppe fescue, etc.) should be carried out with preliminary planning of the slopes with the addition of nutritious soil, with obligatory pinning and subsequent irrigation to ensure the normal growth of the cereals from the first days.

Gas-resistant rocks are recommended for covering slopes where gas emission occurs, including sulfur dioxide, most negatively acting on plants, and where tree-shrub plantings are being spread. Acacia, white-leaved maple, Canadian poplar, yellow acacia, silver hive, tamariks are considered the most stable. These plants have a variety of decorative qualities and make it possible to create colorful compositions of vegetation on the slopes of the dumps. Due to the extremely unfavorable conditions for the growth of tree and shrub species, planting should be carried out in optimal time with compliance with all agrotechnical requirements and with obligatory watering.

\section{Conclusions}

Thus, an analysis of the environmental issues of surface mining shows that the development of the subsoil causes major environmental problems originated from placing the overburden in dumps. Scientifically, eliminating the increasingly obvious discrepancy between the systemic, intensively expanding and deepening open pit mining and damaging the natural environment with man-made objects and processes is held by mainly descriptive, fragmentary knowledge with a poorly developed analytical base. The further research of reclamation issues is due to the need to eliminate directly observable negative environmental consequences of the implementation of local technical solutions. It should be noted that the pace at which the accumulation of new mining ecological knowledge is proceeding is significantly inferior to the pace at which the ecological situation in the mining regions aggravates. The science and practice of mining has a fairly large package of proposals to ensure low-waste operations and resource conservation. The implementation of the new reclamation technologies require some initial costs, and sometimes quite substantial ones. However, there is no other alternative for preserving the environment that is acceptable for ensuring the sustainable development of mining regions but the reclamation.

\section{References}

1. S. Zhironkin, M. Gasanov, G. Barysheva, E. Gasanov, O. Zhironkina, G. Kayachev, E3S Web Conf., 21, 04002 (2017) 
2. M. Tyulenev, S. Markov, M. Cehlar, S. Zhironkin, M. Gasanov, Acta Montanistica Slovaca, 23:4, 368-377 (2018)

3. T. Gvozdkova, M. Tyulenev, S. Zhironkin, V. A. Trifonov, Yu. M. Osipov, IOP Conf. Ser.: Earth Environ. Sci., 50:1, 012010 (2017)

4. M.A. Tyulenev, S.A. Zhironkin, E.A. Garina, Int. J. Min. Miner. Eng., 7:4, 363-370 (2016)

5. M.A. Tyulenev, S.O. Markov, M.A. Gasanov, S.A. Zhironkin, Geotech. Geol. Eng., 36:5, 2789-2797 (2018)

6. O. Litvin, M. Tyulenev, S. Zhironkin, S. Prokopenko, Acta Montanistica Slovaca, 22:2, 146-152 (2017)

7. M. Tyulenev, O. Litvin, M. Cehlár, S. Zhironkin, M. Gasanov, Acta Montanistica Slovaca, 22:3, 296-302 (2017)

8. M.A. Tyulenev, S.A. Zhironkin, O.I. Litvin, E.A. Tyuleneva, O.V. Zhironkina, S.O. Markov, Geotech. Geol. Eng., 35:5, 2065-2077 (2017)

9. M. Cehlár, R. Rybár, J. Pinka, L. Haxhiu, M. Beer, Arch. Min. Sc., 58:2, 557-568 (2013)

10. T.V. Kiseleva, V.G. Mikhailov, Economics and Innovation Management, 4, 70-78 (2018). DOI: $10.26730 / 2587-5574-2018-4-70-78$

11. A. Solovitskiy, O. Brel, N. Nikulin, E. Nastavko, T. Meser, E3S Web Conf., 21, 02012 (2017)

12. M. Cehlár, J. Janočko, Z. Šimková, T. Pavlik, M. Tyulenev, S. Zhironkin, M. Gasanov, 8:1, 21 (2019)

13. A.Selyukov, P. Blištan, S. Jacko, V. Bauer, E3S Web Conf., 41, 01031 (2018) 